\title{
Thermic effect of glucose in obese subjects studied by direct and indirect calorimetry
}

\author{
By Ph. PITTET, Ph. CHAPPUis, K. ACHESON, \\ F. DE TECHTERMANN AND E. JÉQUIER \\ Division of Clinical Physiology and Institute of Physiology, \\ University of Lausanne, I I I Lausanne, Switzerland
}

(Received 8 August I975 - Accepted 8 September 1975)

\begin{abstract}
I. The thermic effect of a glucose load $(5 \circ \mathrm{g})$ was studied in ten control and eleven obese female subjects, using both direct and indirect calorimetry simultaneously. Experiments were done under conditions of thermal equilibrium $\left(28^{\circ}\right.$ and $30 \%$ relative humidity).

2. Thermal balance (heat production measured by indirect calorimetry minus heat losses measured directly) was negative in the control group during the fasting period (heat deficit $-\mathrm{I} 4 \cdot 2 \pm 5^{\circ} \circ \mathrm{kJ} / \mathrm{m}^{2}$ per $\mathrm{h}$ ), whereas that of the obese group was in equilibrium $\left(+\mathrm{I} \cdot 4 \pm 4^{\cdot 8}\right.$ $\mathrm{kJ} / \mathrm{m}^{2}$ per h).

3. After the glucose load, metabolic rate increased $I_{3} \cdot 0 \pm I_{5}$ and $5 \cdot 2 \pm 1 \cdot 3 \%$ in the control and obese groups respectively.

4. In contrast to the metabolic rate, total heat losses were not significantly altered in either group after the glucose load. Total heat losses of the obese group were significantly lower than those of the control group throughout the experimental period.

5. During the experiments the amount of heat stored was increased in both groups. Thermal balance in the control group became positive while that of the obese group remained positive.

6. During the fasting period, the control subjects oxidized more carbohydrates $(90.4$ $\mathrm{mg} / \mathrm{min}$ ) than lipids $(68.8 \mathrm{mg} / \mathrm{min}$ ), whereas obese subjects oxidized more lipids (103.7 $\mathrm{mg} / \mathrm{min}$ ) than carbohydrates $(50.2 \mathrm{mg} / \mathrm{min})$. After the glucose load, the oxidation rate of carbohydrates was increased in both groups to $158.1 \mathrm{mg} / \mathrm{min}$ in control subjects and $95.6 \mathrm{mg} /$ min in obese subjects.

7. The mean skin temperature of the control subjects was significantly higher than that of the obese subjects and remained higher throughout the postprandial period.

8. These results indicate that: $(a)$ during the fasting period, the energy sources utilized and the thermal balance of the two groups were different; $(b)$ the thermic effect of glucose was less in the obese subjects and, therefore, might be a factor contributing to their low energy expenditure.
\end{abstract}

It is widely believed that people become obese because they eat relatively more than non-obese individuals. Thus obesity has for many years been attributed to gluttony, However, this is frequently not the situation (Johnson, Burke \& Mayer, 1956; Stefanik, Heald \& Mayer, 1959).

Many other criteria are involved in the development of obesity: e.g. social, economic and genetic profiles, muscular activity and biochemical characteristics. Galton \& Bray (1967) have reported that the activity of the glycerophosphate cycle is reduced in the adipose tissue of obese subjects, suggesting a more efficient use of energy than in control subjects. Miller \& Mumford (1966), and Stirling \& Stock (1968) suggest that the development of obesity is likely to be due to a thermogenic defect rather than an aberration in appetite, while Linton, Conley, Kuechenmeister \& McClusky (1972) suggest that obese individuals take longer to recognize their feeling of satiety and discomfort with continued eating. Cabanac \& Duclaux (1970) have also reported a deficiency in the satiety response to sucrose in obese subjects. 
Table r. Main physical characteristics of the two groups of female subjects used in the study

(Mean values with their standard errors)

\begin{tabular}{|c|c|c|c|c|c|c|}
\hline \multirow[b]{2}{*}{ Subjects } & \multirow[b]{2}{*}{$n$} & \multirow[b]{2}{*}{$\begin{array}{c}\text { Age } \\
\text { (years) }\end{array}$} & \multirow[b]{2}{*}{$\begin{array}{l}\text { Height } \\
\text { (m) }\end{array}$} & \multirow[b]{2}{*}{$\begin{array}{l}\text { Body surface } \\
\qquad\left(\mathrm{m}^{2}\right)\end{array}$} & \multicolumn{2}{|c|}{ Body-wt } \\
\hline & & & & & $\mathrm{kg}$ & $\%$ ideal wt \\
\hline $\begin{array}{l}\text { Control } \\
\text { Obese }\end{array}$ & $\begin{array}{l}\text { IO } \\
\text { II }\end{array}$ & $\begin{array}{c}24 \cdot 2 \pm x \cdot 7 \\
28 \cdot 9 \pm 3 \cdot 2 \\
\text { NS }\end{array}$ & $\begin{array}{c}x \cdot 69 \pm 2 \cdot I \\
I \cdot 64 \pm I \cdot 7 \\
\text { NS }\end{array}$ & $\begin{array}{c}x \cdot 63 \pm 0.04 \\
x \cdot 90 \pm 0.05 \\
* * * *\end{array}$ & $\begin{array}{c}56 \cdot 6 \pm r \cdot 9 \\
83 \cdot 7 \pm 4 \cdot 4 \\
* * *\end{array}$ & $\begin{array}{l}102 \cdot 0 \pm 2 \cdot 0 \\
159 \cdot 3 \pm 7 \cdot 9 \\
* * *\end{array}$ \\
\hline
\end{tabular}

Ns, not significant.

Differences between mean values for the two groups were statistically significant (unpaired $t$ test): *** $P<0.001$.

The thermic effect of nutrients represents a loss of energy for the body. Since frankly obese subjects can maintain their weight with a lower energy intake than lean subjects, it was of interest to study whether the thermic effect of glucose might be lower in obese subjects than in lean controls.

We studied oxygen consumption, the oxidation rate of lipids, carbohydrates and proteins, total heat losses and thermal balance in two groups of female subjects, after an oral load of $5 \circ \mathrm{g}$ glucose.

\section{EXPERIMENTAL}

Two groups of females who were unfamiliar with the equipment were studied in a direct calorimeter as described previously (Pittet, Gygax \& Jéquier, r974).

The first group consisted of eleven obese females, with no evidence of endocrinological disturbances, and the second was a group of ten healthy, lean female subjects. Their main physical characteristics are given in Table I. Each subject had fasted for $12 \mathrm{~h}$, overnight, and was allowed to rest for $\mathrm{I} h$ in a constant temperature room at $28^{\circ}$ and $30 \%$ relative humidity, before measurements were made. The subject, wearing a minimum of underclothing, was introduced into the calorimeter which was regulated to the same ambient conditions as those of the constant temperature room. Initial (fasting) measurements were taken for $40 \mathrm{~min}$ or until stable values were obtained. The subject was then given an oral dose of $50 \mathrm{~g}$ glucose and the measurements were continued for a further $150 \mathrm{~min}$. The following measurements were made continuously throughout the experiment:

Internal temperature. This was measured using a tympanic and a sublingual probe.

Mean skin temperature. This was estimated by weighting eight different skin temperatures according to the procedure of Hardy \& Du Bois (I937).

Metabolic rate and respiratory quotient $(\mathrm{RQ})$. These were estimated from determinations of ventilation, and the concentrations of $\mathrm{O}_{2}$ and carbon dioxide in the expired air, using an open-circuit system (Gomez, Jéquier, Chabot, Büber \& Felber, I972). Although the RQ can be influenced by changes in ventilation over short periods (i.e. hypo- or hyperventilation) its integration over 30 min periods corrects for these changes and results in a mean $\mathrm{RQ}$ which reflects the true oxidation rate of energy substrates.

The amount of protein (estimated in terms of amino acids) metabolized was cal- 
culated from the urinary nitrogen excretion (Du Bois, 1924). The 'non-protein' RQ was then determined and the tables of Lusk (I924) were used to compute the amount of carbohydrate and lipid (as fatty acids) oxidized during the experiment. Total heat losses were measured by gradient-layer direct calorimetry (Spinnler, Jéquier, Favre, Dolivo \& Vannotti, 1973) which enabled the separate measurement of 'dry' heat losses (radiation + convection) and 'evaporative' heat losses (insensible perspiration and sweating) to be made.

Statistical analyses were done using Student's $t$ test for paired and unpaired results. The threshold of significance was $P<0.05$.

\section{RESULTS}

\section{Metabolic rate and heat losses}

After the glucose load, the metabolic rate, measured over a period of $150 \mathrm{~min}$, increased significantly in both groups (Table 2 ). In the control group, this increase was $13.0 \%$ of the initial (fasting) value, whereas in the obese group it was only $5.2 \%$, i.e. about half the thermic effect found in the control group. This difference in metabolic rate stimulation was highly significant (Table 3 ).

During the $150 \mathrm{~min}$ after the glucose load neither the total nor the 'evaporative' heat losses (which represent about $29 \%$ of the total heat loss) were changed in either group.

However, it is important to note that during the fasting period the total heat losses were significantly higher in the control group (Table 3 ) and that they remained higher throughout the postprandial period.

\section{Oxidation rate of the different substrates}

The mean oxidation rates of the different substrates are shown in Fig. I and Table 4.

During the fasting period the control group oxidized mainly carbohydrate $\left(90^{\circ} 4 \mathrm{mg} /\right.$ min) whereas the principal energy source utilized by the obese group was lipid (103.7 $\mathrm{mg} / \mathrm{min}$ ). The oxidation rates $(\mathrm{mg} / \mathrm{min}$ ) of the other substrates were: control group, 68.8 and 34.8 for lipid and protein respectively; obese group, 50.2 and 26.8 for carbohydrate and protein respectively.

After the glucose load, the oxidation rate of this substrate (carbohydrate) increased significantly in the control group; lipid utilization decreased slightly and protein metabolism remained virtually unchanged. Although there were similar over-all changes in substrate metabolism in the obese group, the fasting level for the oxidation rate of carbohydrate was approximately half that in the control group for the fasting period and, after the glucose load, the value for the oxidation rate of carbohydrate was similar to that in the control group for the fasting period.

Another point of interest is that the high level of utilization of lipid by the fasting obese subjects remained high after the glucose load. 


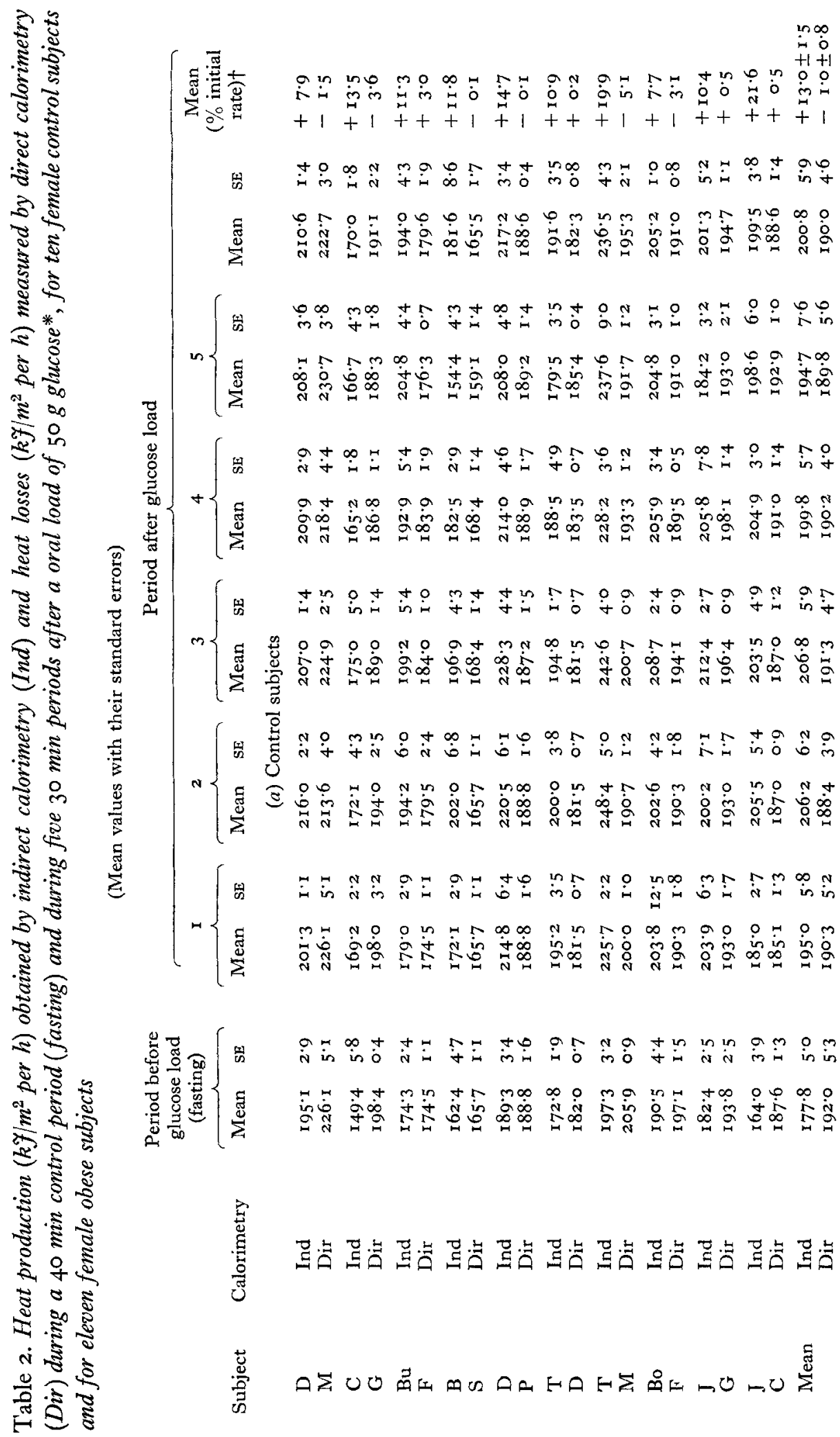




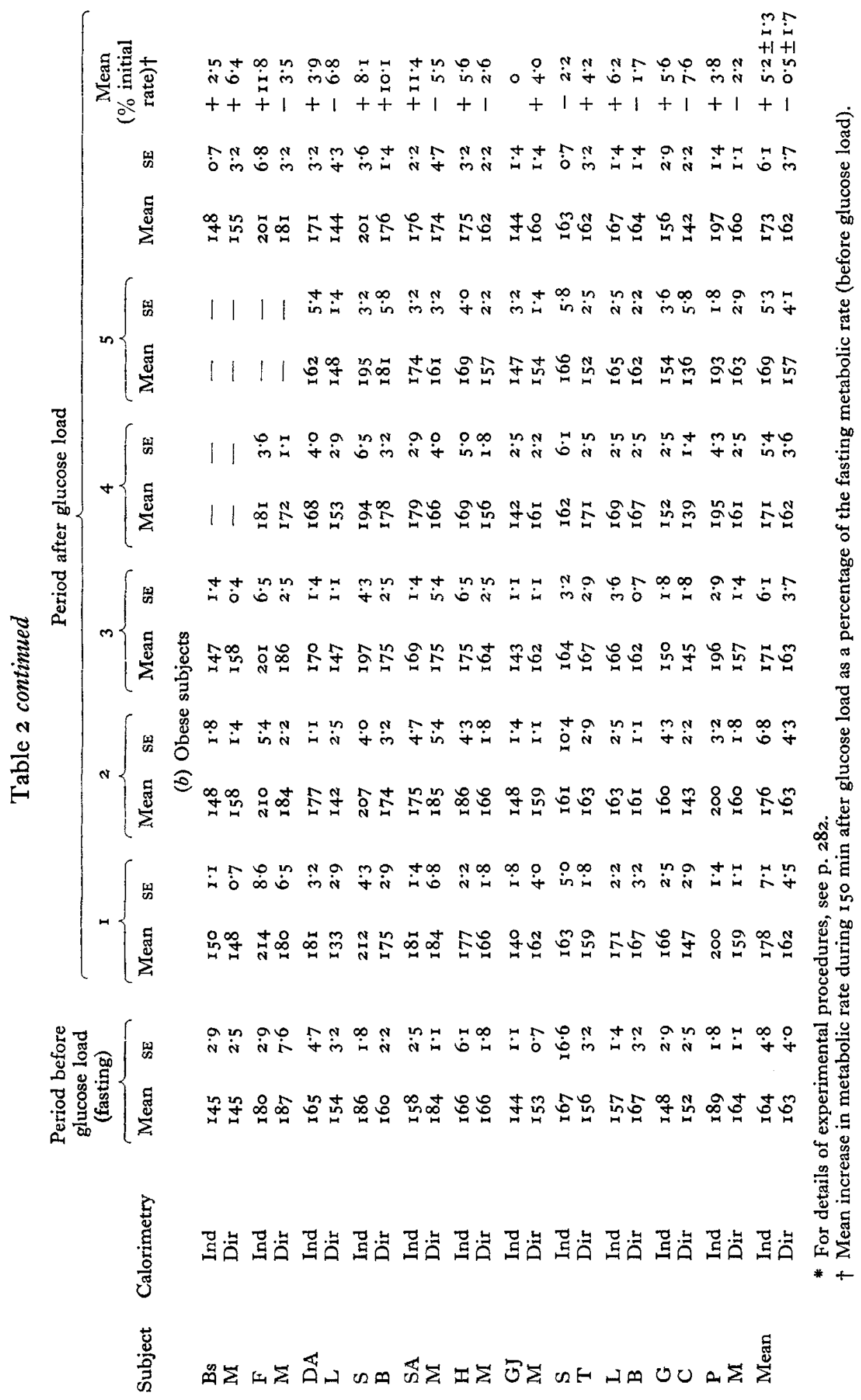


Table 3. Comparison of the metabolic rates and of the total heat losses, before and after an oral load of $5 \circ \mathrm{g}$ glucose, for a group of ten female control subjects and for a group of eleven female obese subjects $\dagger$

(Mean values with their standard errors)

Metabolic rate $\left(\mathrm{kJ} / \mathrm{m}^{2}\right.$ per $\left.\mathrm{h}\right)$

Total heat losses $\left(\mathrm{kJ} / \mathrm{m}^{2}\right.$ per $\left.\mathrm{h}\right)$

Change in metabolic rate (\% initial rate) $\ddagger$

Change in total heat losses (\% initial rate) $\ddagger$

\begin{tabular}{|c|c|c|c|c|}
\hline \multirow{2}{*}{$\begin{array}{c}\text { Period of } \\
\text { measurement }\end{array}$} & \multicolumn{2}{|c|}{ Control } & \multicolumn{2}{|c|}{ Obese } \\
\hline & Mean & $\mathrm{SE}$ & Mean & $\mathrm{SE}$ \\
\hline $\begin{array}{l}\text { B } \\
\text { A }\end{array}$ & $\begin{array}{l}177 \cdot 8 \\
200 \cdot 8\end{array}$ & $\begin{array}{l}5.0 \\
5.9\end{array}$ & $\begin{array}{l}164 \cdot 1 \\
x 72 \cdot 6\end{array}$ & $\begin{array}{l}4 \cdot 8^{\mathrm{NS}} \\
6 \cdot x^{* *}\end{array}$ \\
\hline $\begin{array}{l}\text { B } \\
\text { A }\end{array}$ & $\begin{array}{l}192 \cdot 0 \\
189.9\end{array}$ & $\begin{array}{l}5 \cdot 3 \\
4 \cdot 6\end{array}$ & $\begin{array}{l}162.6 \\
161.8\end{array}$ & $\begin{array}{l}3 \cdot 9^{* * *} \\
3 \cdot 7^{* * *}\end{array}$ \\
\hline & +13.0 & $x \cdot 5$ & $+5 \cdot 2$ & $1 \cdot 3^{* * * *}$ \\
\hline & $-I \cdot 0$ & $I \cdot 5$ & -0.5 & $x \cdot 7^{\mathrm{NS}}$ \\
\hline
\end{tabular}

Ns, not significant; B, before glucose load (fasting period); A, during $150 \mathrm{~min}$ after glucose load. Differences between mean values for the two groups were statistically significant (unpaired $t$ test):

** $P<0.005 ; * * * P<0.001$.

+ For details of subjects, see Table $\mathrm{r}$, and for details of experimental procedures, see p. 282 .

I Mean change during $150 \mathrm{~min}$ after glucose load as a percentage of the fasting value (before glucose load).

\section{Temperatures}

The values for the internal and skin temperatures are given in Table 5. After the glucose load, the internal temperature of the control subjects tended to increase $\left(+0.18^{\circ}\right)$, whereas the mean skin temperature remained unchanged.

In the obese subjects, the glucose load did not cause any significant increase in either the internal or the skin temperature.

The results given in Table 5 indicate that the internal temperature of the control subjects was significantly higher than that of the obese subjects during the postprandial period. Furthermore, the mean skin temperature of the control group was significantly higher than that of the obese group and remained higher throughout the postprandial period.

\section{Thermal balance}

All control subjects were in negative thermal balance (heat production minus heat losses) during the fasting period $\left(-\mathrm{r}_{4} \cdot 2 \pm 5.0 \mathrm{~kJ} / \mathrm{m}^{2}\right.$ per h), i.e. their heat losses were greater than their heat production (Fig. 2). After the glucose load the amount of heat stored increased significantly and the thermal balance became positive $(+10 \cdot 8 \pm 5 \cdot 6$ $\mathrm{kJ} / \mathrm{m}^{2}$ per $\mathrm{h}$ ). However, the obese subjects were already in slight positive balance in the preprandial state $\left(+\mathrm{r} \cdot 4 \pm 4 \cdot 8 \mathrm{~kJ} / \mathrm{m}^{2}\right.$ per $\left.\mathrm{h}\right)$. This positive balance was further reinforced after the glucose load $\left(+10 \cdot 8 \pm 4.8 \mathrm{~kJ} / \mathrm{m}^{2}\right.$ per $\left.\mathrm{h}\right)$.

\section{Energy-free meal}

The possibility that the effects we have found were caused by the glucose carrier were minimal. However, three control experiments were done using three of the lean control subjects to study the effect of an oral load of the same volume but without glucose, i.e. $150 \mathrm{ml}$ water + lemon juice. No significant changes in metabolic rate or 

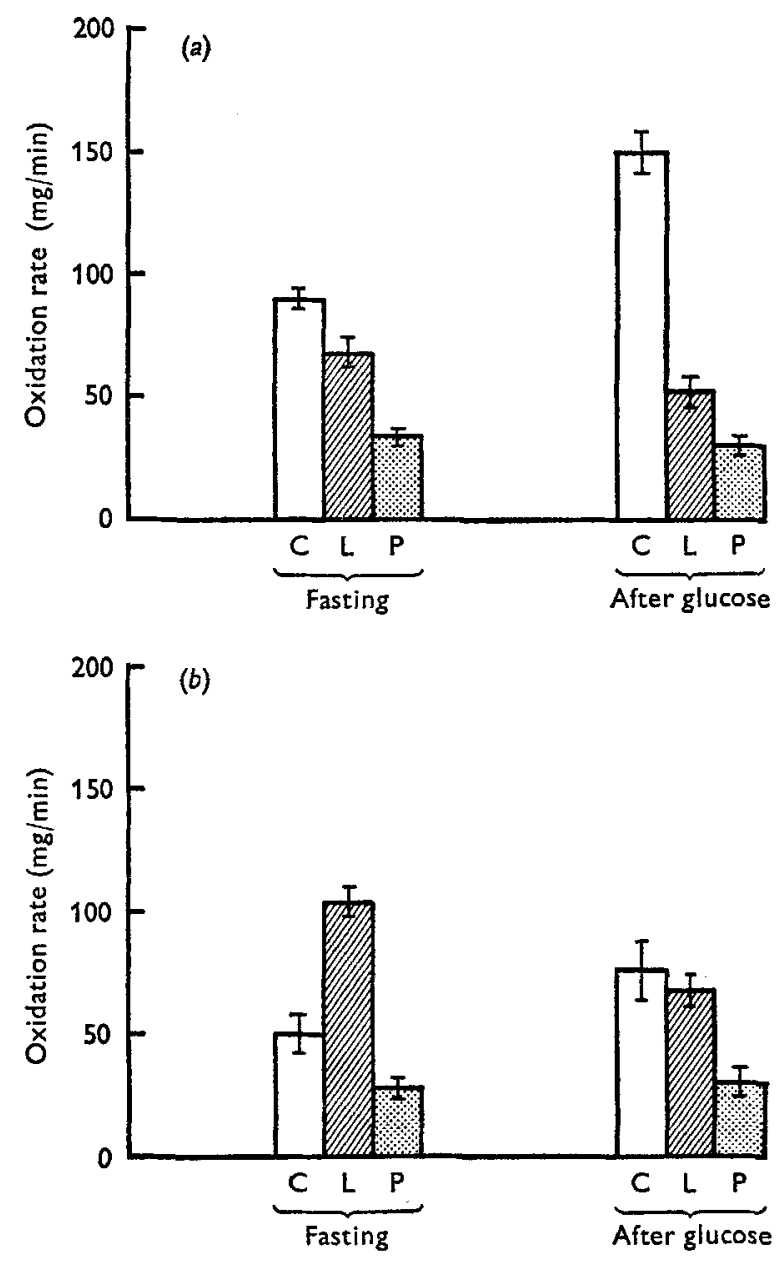

Fig. I. Mean oxidation rates $(\mathrm{mg} / \mathrm{min})$ of different substrates (C, carbohydrates; L, lipids; $\mathbf{P}$, proteins) during a $40 \mathrm{~min}$ control period (fasting) and during $150 \mathrm{~min}$ after an oral dose of $50 \mathrm{~g}$ glucose, for ( $a$ ) group of ten female control subjects and for $(b)$ group of eleven female obese subjects. The increase in the glucose oxidation rate after the glucose load was statistically significant for both groups: $P<0.001$. Vertical bars represent the standard errors of the mean values.

total heat losses were found (Table 6). The negative thermal balance obtained in the fasting period persisted throughout the experiment. Mean skin temperature was not modified but the internal temperature decreased significantly during the experiment (Table 7) confirming the negative thermal balance. The fasting oxidation rates of the substrates were similar to those obtained in the first part of this experiment and were not significantly modified after ingestion of the energy-free meal (Table 7).

On the basis of these results, we can conclude that an energy-free meal of $150 \mathrm{ml}$ water + lemon juice had no significant effect on metabolic rate. Therefore the findings reported in the first part of this study were due to the glucose load. 
Table 4. Mean oxidation rate (mg/min) of carbohydrate, fatty acids (lipid) and amino acids (protein), obtained by indirect calorimetry and from urinary nitrogen measurements before and after an oral load of $5 \circ \mathrm{g}$ glucose, for a group of ten female control subjects and for a group of eleven female obese subjects $\ddagger$

(Mean values with their standard errors)

\begin{tabular}{|c|c|c|c|c|c|c|c|}
\hline \multirow[b]{3}{*}{ Subjects } & \multirow{3}{*}{$\begin{array}{c}\text { Period of } \\
\text { measurement }\end{array}$} & \multicolumn{6}{|c|}{ Metabolites oxidized } \\
\hline & & \multicolumn{2}{|c|}{ Carbohydrate } & \multicolumn{2}{|c|}{ Fatty acids } & \multicolumn{2}{|c|}{ Amino acids } \\
\hline & & Mean & $S E$ & Mean & $\mathrm{SE}$ & Mean & $\mathbf{S E}$ \\
\hline Control & $\begin{array}{l}\text { B } \\
\text { A }\end{array}$ & $\begin{array}{r}90.4 \\
159^{\circ} 1\end{array}$ & $\begin{array}{l}3 \cdot 4 \\
8 \cdot 6 * * * \\
+\end{array}$ & $\begin{array}{r}68 \cdot 8 \\
51 \cdot 8 \\
t\end{array}$ & $\begin{array}{l}6 \cdot x \\
5 \cdot 5^{* *}\end{array}$ & $\begin{array}{l}34 \cdot 8 \\
29 \cdot 6\end{array}$ & $\begin{array}{l}3.0 \\
3.9^{\mathrm{NS}}\end{array}$ \\
\hline Obese & $\begin{array}{l}\text { B } \\
\text { A }\end{array}$ & $\begin{array}{l}50 \cdot 2 \\
95^{\cdot 6}\end{array}$ & $\begin{array}{l}7 \cdot 5 \\
\mathrm{I} x \cdot 8 * * *\end{array}$ & $\begin{array}{r}103.7 \\
88.6\end{array}$ & $\begin{array}{l}6 \cdot 0 \\
7.0 *\end{array}$ & $\begin{array}{l}26 \cdot 8 \\
30 \cdot 0\end{array}$ & $\begin{array}{l}4 \cdot 4 \\
5 \cdot 9^{\mathrm{TS}}\end{array}$ \\
\hline
\end{tabular}

N8, not significant; B, before glucose load (fasting period); A, during ${ }_{50}$ min after glucose load.

Changes in mean oxidation rates for each metabolite for period A were statistically significant:

* $P<0.01 ; * * P<0.005$; *** $P<0.001$.

Differences between mean values for oxidation rates for the two groups for period $B$ and for period $A$ were statistically significant (unpaired $t$ test): $\uparrow \uparrow \uparrow P<0.001$.

$\ddagger$ For details of subjects, see Table $\mathrm{i}$, and for details of experimental procedures, see p. 282.

Table 5. Internal temperature $\left(\mathrm{T}_{\mathrm{int}}\right)\left(^{\circ}\right)$ and mean skin temperature $\left(\mathrm{T}_{\mathrm{cut}}\right)\left(^{\circ}\right)$ measured during the 40 min control period (fasting) (initial $\mathrm{T}$ ) and during the final 10 min (final $\mathrm{T}$ ) of the $\mathrm{I} 5 \mathrm{O}$ min period after an oral dose of $5 \circ \mathrm{g}$ glucose, for a group of ten female control subjects and for a group of eleven female obese subjects $\dagger$

(Mean values with their standard errors)

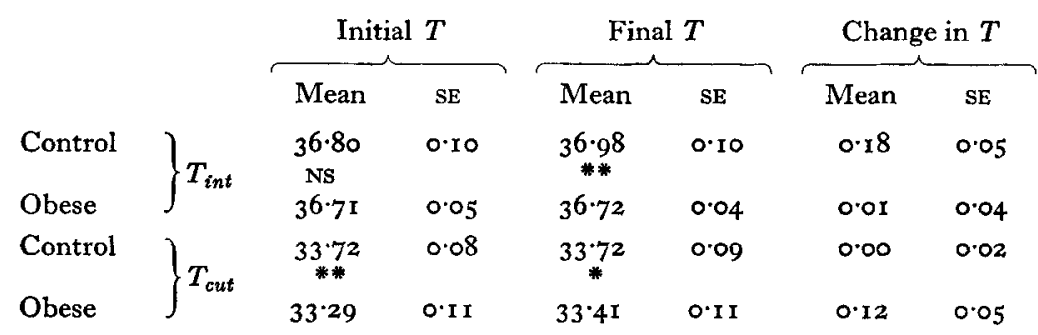

The change in $T$ for $T_{\text {int }}$ and for $T_{\text {cut }}$ for both groups was not statistically significant (paired $t$ test). Ns, not significant.

Differences between mean values for $T_{i n t}$ and for $T_{c u t}$ for the two groups were statistically significant (unpaired $t$ test): * $P<0.05 ; * * P<0.02$.

+ For details of subjects, see Table $x$, and for details of experimental procedures, see p. 282.

\section{DISCUSSION}

Obesity is not always the consequence of an absolute excess of energy intake; this excess can be relative if it is accompanied by a decreased energy expenditure. The main factors contributing to decreased energy expenditure in obese subjects are $(a)$ decreased physical activity, $(b)$ increased energy efficiency of the utilization of nutrients or $(c)$ a lack of thermogenic stimulation, or both $b$ and $c$. 


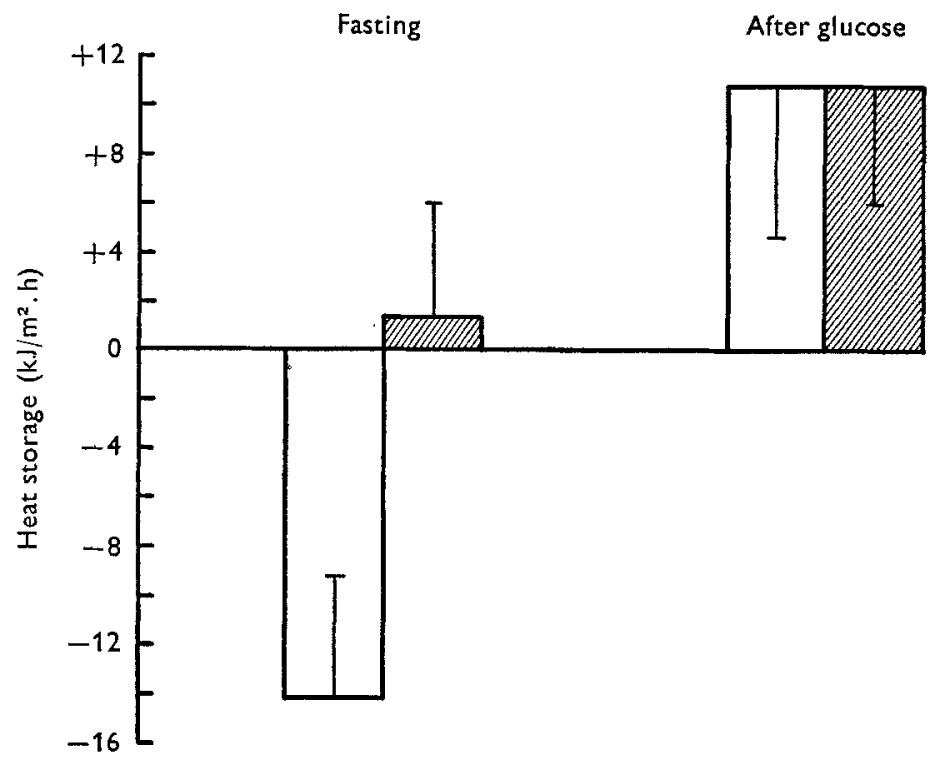

Fig. 2. Mean thermal balance (heat storage $\left(\mathrm{kJ} / \mathrm{m}^{2}\right.$ per h), i.e. heat production minus heat losses) during a $40 \mathrm{~min}$ control period (fasting) and during $150 \mathrm{~min}$ after an oral dose of $50 \mathrm{~g}$ glucose, for a group of ten female control subjects $(\square)$ and for a group of eleven female obese subjects ( The change in thermal balance after the glucose load was statistically significant: for control group, $P<0.001$; for obese group, $P<0.05$. Vertical bars represent the standard errors of the mean values.

It is not the aim of this paper to discuss factors $a$ and $b$ extensively. Decreased physical activity in the obese individual has often been described. Björntorp (I966) has found that lipogenesis from glucose is twice as high in the obese as in 'normal-weight' subjects. There are a few biochemical pathways in intermediary metabolism which can modify energy efficiency, i.e. synthesis of fatty acids from glucose, and oxidation of the glucose produced (Ball \& Jungas, I964), the esterification-hydrolysis cycle for fatty acids (Ball, 1965), and the glycerophosphate-dihydroxyacetone cycle (Galton \& Bray, 1967).

Lack of thermogenic stimulation in the obese individual can be accounted for by a weak, dietary-induced thermic effect, and by a low metabolic response to cold.

The results of this study indicate that at an ambient temperature of $28^{\circ}$, obese subjects have smaller heat losses than control subjects. These results are in agreement with those of Gygax, Pittet \& Jéquier (1972) and Jéquier, Gygax, Pittet \& Vannotti (I974), who reported similar findings at ambient temperatures of 28 and $20^{\circ}$; after $2 \mathrm{~h}$ exposure at $20^{\circ}$, the control subjects tended to stimulate their metabolic rate, but the obese subjects did not.

Our results indicate that, although both obese and control subjects stimulate their metabolic heat production after an oral load of $5 \circ \mathrm{g}$ glucose, this thermic effect was lower in the obese group (only half that of the control group).

The fasting oxidation rates of the different substrates were different in the obese subjects when compared with the control subjects. The latter oxidized more carbo- 


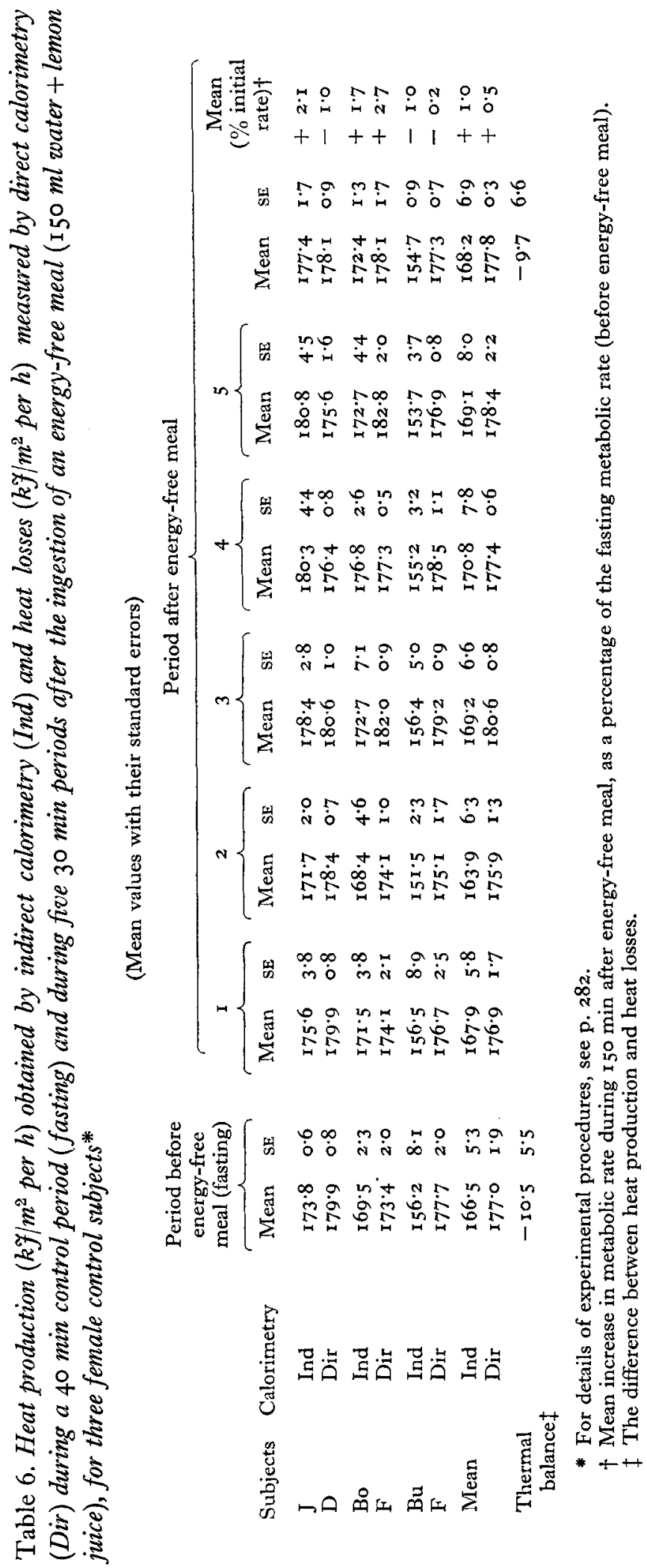


Table 7. Internal temperature $\left(\mathrm{T}_{\text {int }}\right)\left(^{\circ}\right)$ and mean skin temperature $\left(\mathrm{T}_{\mathrm{cut}}\right)\left({ }^{\circ}\right)$ measured during the 40 min control period (fasting) and during the final 10 min of the $150 \mathrm{~min}$ period after the ingestion of an energy-free meal ( $150 \mathrm{ml}$ water + lemon juice), and mean oxidation rate ( $\mathrm{mg} / \mathrm{min})$ of carbohydrate, fatty acids (lipid) and amino acids (protein) obtained by indirect calorimetry and from urinary nitrogen measurements before and after the meal, for three female control subjects $\dagger$

(Mean values with their standard errors)

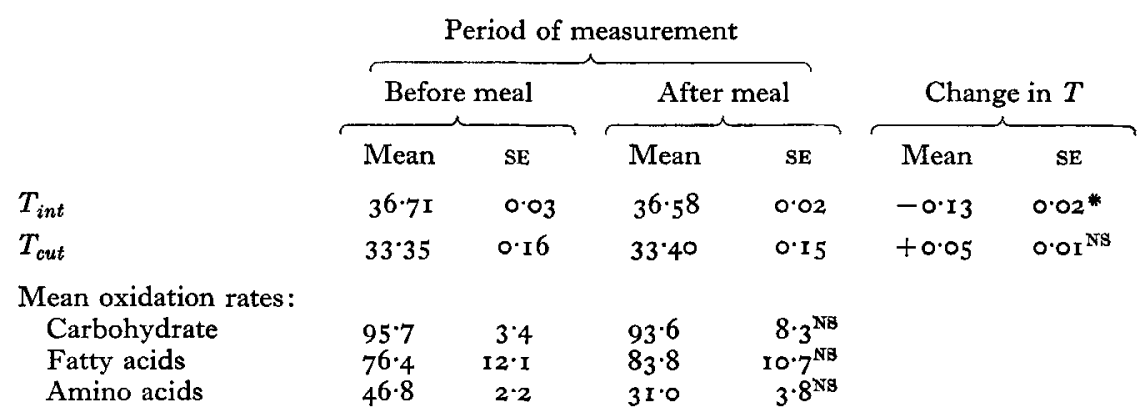

Changes in mean oxidation rates for each metabolite after the energy-free meal were not statistically significant.

$\mathrm{Ns}$, not significant.

The change in $T$ for $T_{i n t}$ was statistically significant: $*<<0$.

+ For details of experimental procedures, see p. 282 .

hydrate $(90.4 \mathrm{mg} / \mathrm{min})$ than lipid $(68.8 \mathrm{mg} / \mathrm{min})$, whereas the fasting obese subjects oxidized more lipid (103.7 mg/min) than carbohydrate $(50.2 \mathrm{mg} / \mathrm{min}$ ). After the glucose load there was an increase in glucose metabolism in both groups, but it was much lower in the obese than in the control subjects.

Felber, Moody \& Vannotti (1965) reported a decrease in the glucose tolerance of non-obese subjects when the concentration of circulating free fatty acids is increased by an infusion of lipids preceding the glucose load. Gomez et al. (1972) suggested that this glucose intolerance was probably due to inhibition of carbohydrate oxidation rate by metabolites of free fatty acids as described by Randle, Hales, Garland \& Newsholme (1963) in muscle tissue. A similar mechanism could account for our results in obese subjects.

In our ambient conditions, the thermal balance obtained indicated that the two groups were in a different starting state. The fasting control subjects were in negative thermal balance, their heat losses were greater than their metabolic heat production and their temperatures tended to decrease. On the other hand, fasting obese subjects were in thermal balance, their metabolic heat production was slightly higher than their heat losses and their body temperature was stable.

The ingestion of the glucose induced an important modification in the thermic state of the control subjects: from a negative level, i.e. from a deficit of heat, they reached a positive thermal balance.

In the obese subjects, ingestion of the glucose did not cause such an important 
change in their thermic state. Glucose ingestion only induced a reinforcement of a pre-existing, equilibrated thermal balance.

Thus, the results of this study suggest that an inefficient stimulation of thermogenesis might be a factor contributing to the low energy expenditure of the obese individual. This decreased dietary-induced thermic effect may be due in part to inhibition of glucose oxidation by fatty acid metabolites.

It remains to be determined whether the equilibrated thermal balance of the obese individual is involved in inhibiting the thermic effect found after glucose ingestion. The thermic effect of protein and lipid should also be carefully studied in the obese individual.

The authors thank Mrs M. Marmier and M. Oberti for their skilful technical assistance. Financial support from the Nestlé Company, Vevey, Switzerland, is gratefully acknowledged.

\section{REFERENCES}

Ball, E. G. (1965). Ann. N.Y. Acad. Sci. 131, 225.

Ball, E. G. \& Jungas, R. L. (I964). Recent Prog. Horm. Res. 20, I83.

Björntorp, P. (1966). Acta med. scand. 179, 229.

Cabanac, M. \& Duclaux, R. (1970). Science, N.Y. 168, 496.

Du Bois, E. F. (1924). Basal Metabolism in Health and Disease, Ist ed., p. 23. Philadelphia: Lea and Febiger.

Felber, J.-P., Moody, A. J. \& Vannotti, A. (1965). Helv. med. Acta 32, 323.

Galton, D. J. \& Bray, G. A. (1967). F. clin. Endocr. Metab. 27, r 573 .

Gomez, F., Jéquier, E., Chabot, V., Büber, V. \& Felber, J.-P. (1972). Metabolism 2r, $38 \mathrm{r}$.

Gygax, P.-H., Pittet, Ph. \& Jéquier, E. (1972). Experientia 28, 728.

Hardy, J. D. \& Du Bois, E. F. (1937). F. Nutr. 15, 5.

Jéquier, E., Gygax, P.-H., Pittet, Ph. \& Vannotti, A. (1974). F. appl. Physiol. 36, 674.

Johnson, M.-L., Burke, B. S. \& Mayer, J. (1956). Am. F. clin. Nutr. 4, 37.

Linton, P.-H., Conley, M., Kuechenmeister, C. \& McClusky, H. (I972). Am. F. clin. Nutr. 25, 368.

Lusk, G. (1924). F. biol. Chem. 59, 41.

Miller, D. S. \& Mumford, P. (1966). Proc. Nutr. Soc. 25, roo.

Pittet, Ph., Gygax, P.-H. \& Jéquier, E. (1974). Br. J. Nutr. 31, 343.

Randle, P. J., Hales, C. N., Garland, P. B. \& Newsholme, E. A. (1963). Lancet i, 785.

Spinnler, G., Jéquier, E., Favre, R., Dolivo, M. \& Vannotti, A. (1973). F. appl. Physiol. 35, I 58.

Stefanik, P.-A., Heald, F.-P. \& Mayer, J. (r 959). Am. F. clin. Nutr. 7, 55.

Stirling, J. L. \& Stock, M. J. (1968). Nature, Lond. 220, 80 I. 